\title{
Playing God in Academe
}

\section{Raymond J. Rodrigues}

Colorado State University

In 1986, Alston Chase published his book Playing God in Yellowstone. In it, he argues that Yellowstone had never, in historic times, ever been in a truly natural state. He points out that when the early European and Anglo explorers first entered Yellowstone, fires were burning everywhere. The fires, he tells us, were set by the Indians in Yellowstone to drive game into areas where they could be trapped and killed. In setting those fires, the Indians were actually controlling and contributing to the ecological balance of the region.

When the National Park Service took over the area, they began to institute their own controls. For example, they systematically wiped out all the wolves in the park. Years later, they realized that the wolves had actually contributed to the ecological balance in the park; around this time, wolves suddenly started to be sighted in various areas around the park. The Park Service claimed that a pack of wolves had somehow survived in the interior of the park, and that they now were proliferating and spreading out. But strangely, all pictures of the wolves showed them running away from the camera, sometimes by roads and power lines. Then, ranchers north of the park started to report wolves, and soon, ranchers north of them. In the park, wolves were no longer seen. The Park Service, it seems, had trapped the wolves in Canada and released them in Yellowstone; now the wolves were headed back home.

If you are like me, you grew up with the warnings of Smokey the Bear - "Remember, only you can prevent forest fires." Even today, starting a campfire in the forest, I am filled with fear. Alston Chase argues that the forests of Yellowstone were overgrown because of a misguided fire policy of the Park Service. The forests had grown so large that underneath the trees they were dead. Only a few squirrels and birds lived in them. Beavers had no forage, so they left. With no beaver dams, swampy areas disappeared. With no swampy areas, the larger animals had less forage. In their 
attempt to do what was right, the Park Service had actually harmed the forest.

And then this summer came, and the forests of Yellowstone burned. They are still burning as we meet today.

Some are calling for the resignation of the park superintendent. He's an alumnus of Colorado State, and in our recruiting booklet, we have a picture of him standing before Mammoth Hot Springs, saying, "If it weren't for Colorado State, I wouldn't be where I am today." I enjoyed kidding our director of admissions about that, and I wish that when I was an English teacher in high school, I could have located such beautiful examples of irony.

But what has the tragedy of Yellowstone to do with you? Why did I find the idea of "playing God" so attractive when I was asked to provide a title for my speech today?

Can you accomplish anything without upsetting the tension that is, for all its problems, the essence of the modern university? When we consider it, your position within a university is very much like that of the National Park Service in Yellowstone. Do you recommend setting fires? Or do you argue against setting fires? Should you just let nature take its course and hope for the best, or should you step in and recommend changes and actions that seem to work against what others may consider to be the natural course of affairs? And regardless of what you believe to be right, how will people react to your suggestions?

I could tell you that I appreciate your efforts - because I do - but that would be much like Dan Quayle saying that he is qualified to be President. No, what I feel toward you is massive sympathy, because you have to deal with faculty, departments, and universities whose values are in conflict. Just as the National Park Service in Yellowstone had to deal both with tourists who wanted to see pristine wilderness and with environmentalists who wanted the forests treated naturally, so you must deal with the conflicting values within your universities and colleges. If I could offer any insight at all, it is that you and I have to work with the conflicting values of our faculty colleagues if we are to have any impact at all.

Gerald Graff, in a February 17, 1988, "Point of View" opinion in the Chronicle of Higher Education, addresses just that issue when he suggests ways to deal with ideological and methodological conflicts in academe. In fact, he suggests an approach that I will return to near the end of my talk: "Why not start thinking of ideological and methodological conflict as an opportunity to be exploited rather than as a paralytic condition to be cured?" 
Consider some of the key areas where faculty values clash. They clash over the issue of research vs. teaching. They clash over what content to teach. And they clash over whether process matters more than content. We have heard and read the constant attacks of people like William Bennett who insist that the emphasis upon process has taken the content out of the curriculum. According to this argument, process divorced from content is meaningless, and somehow the argument has been corrupted to the point that content has become the end of all learning. The epitome of this argument has been the publication of E. D. Hirsch's Cultural Literacy.

Hirsch's argument is based upon his interpretation of schema theory. Briefly, a reader becomes a better reader, not by being able to read more rapidly, but by increasing comprehension. And comprehension increases when the reader can relate his or her experience and knowledge to what he or she is reading. The schema, or bridges from knowledge to reading, increase understanding. So, Hirsch suggests something very simple: increase a person's working vocabulary and you increase that person's comprehension. I doubt that many reading researchers would question that, although they would argue that schema derive from all the life experiences of an individual. Simply memorizing lists of words does not mean that you are literate in your use of those words. Furthermore, when Hirsch suggests a list of words and terms that every literate American should know, those who are against process use that list to argue that the more content you teach, the better able students will be to comprehend what they read, and the better citizens they will become.

The arguments that have ensued have encompassed the cultural narrowness of Hirsch's list (for example, the word "pueblo" is not there, nor are any Russian authors or composers) as well as the concern about whether teaching a list of words truly makes one literate. These arguments are rooted in values, those deeply felt beliefs that are so difficult to erase. And conflicting values explain why we find it so difficult to move faculty thinking. But if we don't address those values, we will not change anyone.

Let me address the process vs. content argument in my own field, English composition. Fifteen to twenty years ago, it was thought that a teacher could teach writing by merely presenting the format and content of a piece of writing. Today, writing teachers feel that they have an obligation to help their students learn the process of writing - the movement from beginning to think about what to write through revision and editing. 
For generations of English teachers, the standard approach to teaching writing was to assign an essay due a week later, collect the essay, write comments on it, grade it, and hand it back to the student. For generations, students looked at the grade, ignored the comments, and threw their papers in the waste basket.

I was one of those English teachers myself. And I will bet that most of you were those students. My teachers had beaten it into my psyche that if I did not assign at least one paper a week, did not go home and work into the dark hours of the night, did not note every mistake I could find, then I was not doing my job as an English teacher. My mother brought me up with guilt. My former English professors and English methods professors brought me up with guilt.

And I am here to tell you that every professor teaches the way he or she teaches because of generations of professors who taught them that way themselves. If values are not firmly rooted after that, why else do they persist?

After the students would throw their papers away and make the same mistakes the next time they wrote, we English teachers would sit around complaining about how hard we taught them and how little they learned. Were we poor teachers? Absolutely not! In fact, I will argue to this day that I was one of the best teachers my students had. And a few of them might even agree.

What has happened since I taught English in high school is that the discipline has undergone a classic paradigm shift. What happened? Researchers began to ask a very basic, but essential, question: how do people who write regularly actually write? How do professional writers write? What do they do to get to the final product? The researchers began to look over the shoulders of bankers while they wrote letters to delinquent borrowers - and ask them why they phrased things the way they did. They followed research teams around, noting how they prepared their research reports, how technical writers interacted with them to write the reports for them, how they revised their reports, who approved the reports.

And what did they learn? Well, one of the most important things that they learned was that very few people actually write as individuals, alone at their desks, living in some Reaganesque cowboy fantasy of the brave individual facing the world and beating it. What they learned was that virtually no one writes alone, with the possible exception of novelists or short story writers or poets - and even they often have editors who offer advice on how to improve their writing. Did John Kennedy write those speeches that we remember so well? Of course not. Ted Sorensen was the 
key author. Does Michael Dukakis write his formal speeches? Listen again to the parallel structure. That's Ted Sorensen again.

What the researchers learned was that most people outside school collaborate with others when they write. Look at what goes on among faculty. Count the number of committee reports written by a group of faculty. Try to make sense of your faculty senate manual. How many people write grant proposals alone? How many faculty collaborate on articles and books? Yet, so many faculty insist that students must write their papers by themselves. They do so because that is what they have been taught to value.

What else did the researchers learn about "real world" writing? They learned that writers engage in a variety of tasks that the researchers and theorists call "writing process." At first, they tried to systematize that process, but they soon discovered that it was not very neat. Some writers plunged right into their writing and discovered what they wanted to say. Others talked to people to get ideas, jotted ideas down on scraps of paper, wrote loose, rambling drafts before settling in upon something that approached a serious draft. Many revised as they wrote. Some got halfway through, decided they needed more information, and went back to generating ideas or conducting research. Finally, they cleaned it upedited it - and made it presentable for their readers.

So, we now have a new paradigm in teaching writing that realizes that collaboration is productive, that each person's process differs from that of other people, and that writers do not write in a vacuum, but in a specific context and with specific content. Moreover, the paradigm directly contradicts the values that English teachers once shared.

What does all this mean for you and others like you who are trying to develop the ability of faculty to improve their teaching? To me, it means that we cannot offer workshops on generic skills and convince faculty that they should change what they have always believed to be right.

So we or the people we select to help develop the teaching skills of faculty have to be prepared to learn what the specific discipline expects and to make the most of that. Math teachers and science teachers and art teachers are also concerned with process, but many of them do not overtly realize that. If an English teacher is to help them teach writing across the curriculum, then that English teacher must know how their disciplines understand the process of learning and doing.

I have always been bothered by the mathematics module courses at my current and former universities - not because they do not work, but because they work for only one type of learner. For students who learn as 
individuals, who are self-motivated, they are wonderful. But other students learn best from real professors in structured classroom settings or in group settings.

A recent study tried to determine why Asian American students in one university seemed to do so well in mathematics and why black students in the same university seemed to do so poorly. Just like the writing researchers before them, these mathematics researchers looked at the students while they tried to learn. What they discovered was that the Asian American students tended to get together and study in groups, asking each other questions, helping each other over difficult spots, while the black students tried to go it alone, studying by themselves. So, the researchers forced a group of black students to study together, to share ideas and problems, to collaborate in their learning. The result was that the black students began to make progress and succeed. Now we can teach our math professors something: encourage your students to collaborate. Show them how to work together.

It may be that mathematics professors are all self-motivated learners who learn very well alone. It may be that those who were not self-motivated and individual learners never became mathematics professors. It may be that mathematics professors are themselves the worst possible examples of what it takes to learn mathematics because they are the exceptions in the general populace. What they value may be fine for mathematics researchers and theorists, but inappropriate for most mathematics learners.

So, what can we do? How do we appeal to the ingrained values of our faculty colleagues? To appeal to some, we may have to invoke the idea of research. For some, conducting research in their classroom may be a way to link teaching with the real rewards for research. In a university such as mine, when we link research and teaching, then we are making the task of the professor rewarding and meaningful. Even though $I$ have spoken of research, I do not mean research to be narrowly defined. Ernest Boyer, in his College: The Undergraduate Experience in America, argues that "scholarship is not an esoteric appendage; it is at the heart of what the profession is all about." Scholars must be prepared to confront differences in opinions and values.

The next obstacle that we have to overcome is the culture of the department in which the professor resides. Some departments have responded to me, when I have proposed that they link teaching and research, that such research is inappropriate for them, that they simply do not do that type of research. Sometimes, these very narrow attitudes 
toward research lead to unfortunate results. For example, an unfortunate event occurred on my campus shortly after I arrived. One of the jobs of our office is to review tenure and promotion actions for all professors. We ask one basic question: Has the department followed all the appropriate procedures, including the need to keep the untenured professor fully apprised of how the department views his or her progress? In this case, a department had refused tenure for an assistant professor because her research was not considered appropriate for that discipline. All the procedures had been followed. The department head had informed the professor in writing that her research was inappropriate, and she had signed the evaluations indicating that she had read the evaluation. Yet, she did conduct research. She published. She acquired grants. And had she been in another department in the same college, she would have been easily tenured. One can argue that some accommodation should have been reached before she entered the final tenure year. One can argue that she should have been released earlier. One can argue that she should have been offered a position in a more appropriate department or that a mentor should have been assigned to her or any of a variety of equally humane and reasonable solutions. But it had not happened. And it had not happened because the values of the department had not allowed it to happen.

In his Chronicle "Point of View" essay, Gerald Graff argues that "a curriculum in which conflicting interpretive contexts and theories were negotiated out in the open would not be a retreat [from the classical studies], but a way of helping students make sense of it."

When I arrived at our campus, I stepped into the middle of the outcomes assessment arguments. Those arguments, unfortunately, were conducted in Faculty Council committees. They were literate, serious, exciting arguments. Unfortunately, they occurred within the committee meetings where other faculty and students could not join in. What a massive shame. Our Faculty Council process had worked against the greatest possible good that could result from these discussions-open debate, open disagreement, open conflict of values. In being safe and proper, we had undercut the very essence of a university - the sharing of ideas, values, ideologies, and approaches.

Graff suggests three possible ways to deal with the public sterility and fear of open conflict that permeates so many colleges and universities: "metacourses" in which several disciplines work together to address the broad contexts of any given course; instructors sitting in on each other's classes; and "multicourse conferences," in which a department sets aside 
a week or two out of the semester to engage their majors as a group, a professional conference that students and professors both attend to hear the variety of opinions and ideas present in their numbers.

If only we knew how to communicate with one another. If only we understood the jargon and language of each other's fields. Even when we understand each other's language and pedagogy, we may not want to copy them wholesale - but by sharing our ideas, we encourage more convergent thinking.

The Association of American Colleges' new report, $A$ New Vitality in General Education, may reinforce much of what you already believe in. For example, the report suggests that:

A. Professors reorient their teaching to how students learn, being concerned as much with how as with what.

B. Faculty members sit in on each other's general education classes to demonstrate how much they value the teaching and content of other fields. (By talking and learning from one another, they can demonstrate how much they value the integration of knowledge.)

C. Each university or college create a think tank on curriculum and pedagogy and that administrators reward work in these think tanks.

Happily, the report defends colleges of education, pointing out that the research done on learning in the recent past has been serious and meaningful (and, I would add, perhaps the most valuable research in the university world).

The report is a defense of general education, a set of suggestions on how to make general education more meaningful. Some of us come from universities where the general education curriculum is little more than a menu of courses that were selected through political negotiation, and where the goals and objectives for undergraduate education are little more than motherhood, apple pie, and the American flag wrapped up in professional jargon. But I believe that the faculty who have found themselves caught up in political haggling over turf-bound jargon each originally had the best interests of students in mind. They simply have found it difficult to escape their professional values.

The report recommends a variety of teaching techniques that should sound familiar to you:

A. Encourage collaborative learning, using small groups, and walk among the groups to help them.

B. Use electronic media, computers, interactive video, and telecommunications (but, I would add, use them in ways that are most meaningful for your discipline). 
C. Create laboratory experiences without laboratories. Explore the roots of scientific knowledge, how researchers came to their conclusions. Why have students bog down in cutting their hands molding glass when they can spend their time more profitably in the excitement of discovery? Can students spend more time discussing scientific ideas and less time trying to get a good grade on a laboratory experiment?

D. Encourage out-of-classroom learning, using field experiences, internships, practica, and a wide variety of projects.

E. Link the general education courses to the various majors that students will be in. English composition courses are often considered meaningless by students when the courses emphasize writing in an intellectual vacuum. Students view mathematics problems as abstractions when they have little bearing upon their eventual use. Many view social science courses as places where they learn disjointed facts and seldom have their values challenged or learn what it means to be a citizen.

If we begin to find ways to break down the boundaries of narrow disciplinary studies, we are going to have to confront a more serious set of values - the belief that the knowledge in our field is set and that the classics of our field are innately classics. We know that knowledge is socially constructed. That is, the knowledge that we are transmitting is knowledge that has been agreed to as a result of social and historical events. Just as what we call a "standard English dialect" is little more than a result of some groups having achieved power over others and has nothing to do with whether one dialect is qualitatively better than another, so all the knowledge we choose to transmit is knowledge that those in power have deemed to be worthwhile.

The books we call "classics" are classics because historical contexts have enabled them to survive, not because they are necessarily better written than those books we no longer remember. When we begin to deal with what knowledge is worth knowing, however, then we are truly treading upon people's values. But how exciting the debate about traditionally held values can be.

When we bring faculty together to debate the values that they believe in, when we invite students to those debates, when the clash in disciplinary cultures becomes a public clash, then we will begin to influence the thinking of our professors, stimulate them, and, eventually, stimulate our students more than we currently do. Ideas are exciting. That is why most of us went into higher education in the first place. How did we lose the 
enthusiasm? Why can't we engage our students more than we currently do? I am convinced that university faculty are hungry for the clash of ideas and values.

So, do we dare play "God in Academe?" Do we dare drop a few apples in front of Dr. Adam and Dr. Eve? Are we afraid of starting a few fires and letting them burn?

In Peter Drucker's September/October 1988 article in the Harvard Business Review, "Management and the World's Work," he points out that Zeiss Optical Works lost its world leadership position when its workers preferred "immediate satisfaction - higher wages, bonuses, benefits - to investing in research, new products, and new markets." We cannot allow faculty to lose sight of the long-range future in trying to improve tomorrow's immediate rewards.

It may take a hundred years for the trees of Yellowstone to grow back and mature, but Yellowstone will be a better environment as a result of this year's fires. Even now, new grass has grown where the fires began. Did you know that the seeds of lodgepole pines will not even germinate unless they have been in a fire? And the animals of Yellowstone-those who survive this winter - will return in the spring to an environment where they can thrive.

It may take a hundred years to change the essence of our universities, but they need a few fires set. New ideas will spring up immediately. Lasting ideas will begin to germinate. Play God. It's the best thing you can do. 